\title{
The role of green manure crops in Hungarian plant production
}

\author{
Ágnes Fekete - Péter Pepó \\ University of Debrecen, Faculty of Agricultural and Food Sciences and Environmental Management, \\ Institute of Crop Science, Debrecen \\ fekete.agnes.91@gmail.com
}

\begin{abstract}
SUMMARY
According to the data of KSH (Hungarian Central Statistical Office), the sowing area of cereals in the crop year 2016 was over 2.56 million ha, on which winter wheat and maize were produced in a rate of around 50-50\%. Regarding these data it is obvious that the domestic cropping structure has been simplified and become unilateral. This unfavourable crop rotation system causes several problems. The number of Hungarian livestock decreased in the past decades. The amount of manure was 24 million tons in 1960, but only hardly 4.5 million tons of organic manure was applied in 2016. Therefore, the importance of other possibilities, alternatives for organic matter recovery have become enhanced. This is especially important from the aspect of sustainable plant production. The fact that the European Union has introduced new directives for subsidiaries in 2015 has to be noted as well.

The objective of the set experiment is to find new technological solutions that are suitable for the execution of sustainable plant production by inadequate crop rotation, organic substance recovery conditions or under more unfavourable climatic conditions.
\end{abstract}

Keywords: green manure, fertilization, yield, dry matter, biomass, organic matter, legumes, cruciferous plant, soil, alternative plant nutrition

\section{INTRODUCTION}

The area of cropland had decreased by 1.9 million hectares in the past decade (FAOSTAT). However, the decrease of demand on crop products is not a consequence of the decrease of cropland area. The basic objectives are the enhancement of crop production efficiency, just as the production of maximum yield amount per unit production area parallel to the implementation of sustainable crop production practise.

According to the data of KSH (Hungarian Central Statistical Office) sowing area of cereals in the crop year 2016 was over 2.56 million ha, on which winter wheat and maize were produced in a rate of around $50-50 \%$. Regarding these data it is obvious that the domestic cropping structure has been simplified and become unilateral. This unfavourable crop rotation system causes several problems. Due to the unilateral plant production soil conditions may deteriorate, several nutrient supply, plant protection and water supply problems may occur. Intensive, large-scale plant production and agronomical measurements result in further soil problems. From the 90's the average yield of maize per hectare increased from 3.9 to 8.6 tons and in case of winter wheat an average yield of $5.3 \mathrm{t} \mathrm{ha}^{1}$ is quite common now. For such outcomes professional and targeted plant protection management, production that decrease any stress on soil and climate, just as harmonic nutrient supply are essential. Based on the data of $2016(\mathrm{KSH})$ it can be stated that the amount of applied mineral fertilizers per hectare has been almost doubled $(103 \mathrm{~kg})$ in the past 20 years. However, lacking and expensive fossil resources mean a huge gap in sustainable plant production. Furthermore, it has to be added that the number of Hungarian livestock decreased in the past decades. Amount of manure was 24 million tons in 1960, but only hardly 4.5 million tons of organic manure was applied in
2016. It means that some fields were not fertilized with organic manure for even decades.

Therefore, the importance of other possibilities, alternatives for organic matter recovery have become enhanced. This is especially important from the aspect of sustainable plant production. The fact, that the European Union has introduced new directives for subsidiaries in 2015 has to be noted as well. Main target of the greening programme is to achieve, that those who carry out agricultural activities contribute even more to the preservation of the environment and natural resources that mean the basis of agricultural production (NAK 2017). According to the data of the Research Institute of Agricultural Economics it can be stated that the production area of green manure crops was less than 40000 hectares before 2015, but after the introduction of the new subsidiary system their sowing area was doubled in Hungary. The targeted cropping area of green manure crops in 2017 was over 86000 , 26000 ha of which was planned to be sown in the Southern Great Plain region (Research Institute of Agricultural Economics 2013, 2017).

There are several methods for the recovery of organic matter. One is if plant organic substances and by-products are tilled into the soil, the other is if different green manure crop species and/or their mixture are sown directly. Both organic residues and green manure plants help to preserve or even the enhancement the organic matter stock of the soil and to improve the quality and quantity of humus substances.

The application of green manure is a millennial method in crop production. Its importance is increasing nowadays, even if the modernization of manure treatment and its adequate application in the $19^{\text {th }}$ century, just as the propagation of mineral fertilization in the $20^{\text {th }}$ century have mostly eliminated it (Füleky 1999). Green manure means that living, green, succulent, only slightly senescent plants that contain high amount of sugar, starch and proteins, just as nitrogen are tilled 
into the soil and parallel to that the living roots of the plants are destroyed as well (Kahnt 1986). Or according to the definition of Szabó (2003) green manure is fresh and green biomass that is suitable for nutrient supply and the improvement of soil structure. Birkás (2017) has defined the target of green manure production as follows 'Green manure plants serve the maintenance of soil fertility and the enhancement of its agricultural state'. According to Antal (1993) advanced green manure crops can be sown after cereals or other plants, after that the main pre-crop - harvested during the summer before - during autumn or in the springtime and they develop after the harvest of the main crop in the second half of summer.

Several authors classified green manure crops into two main groups (Kahnt 1986, Antal 1993, Birkás 2017). Traditional green manure crops are legumes. Their determining role in crop rotation systems was defined by Antal (2005) as follows: 'bacteria (Rhizobium) colonize on their root and form nodules that are able to fix atmospheric nitrogen; this relationship develop into symbiosis between bacteria and plant, while plant is provided with high amount of nitrogen thus'. According to (Kahnt 1986, Antal 1993 Szabó 2003 Birkás 2006) the most important legumes sown on weak, acidic, light sandy Hungarian soils are lupins (Lupinus), white sweet clover (Melilotus albus L.), hairy vetch (Vicia villosa Roth) and red clover (Trifolium pratense L.).

The other main group of green manure crops cover cruciferous and other beneficial plants. Their common attribute is that they maintain loose soil structure and produce high amounts of biomass (Birkás 2017). Fodder radish [Raphanus sativus L. convar. oleiferus (Mill)] that has short vegetation period and nematocide effect, white mustard [Raphanus sativus L. convar. oleiferus (Mill)] that has a deep root system and rape (Brassica napus var. annus) are commonly used on Hungarian fields (Antal 1993). However, in their experiment between 2004 and 2009 Talgre et al. (2012) stated that birdsfoot trefoil (Lotus corniculatus) is less suitable as green manure plant; furthermore red clover (Trifolium pratense) and hybrid alfalfa (Medicago sativa) produce significantly higher biomass than birdsfoot trefoil. Plants that protect against wind and water erosion, just like California bluebell (Phacelia tanacetifolia) and green rye (Secale cereale L.) are classified as plants applicable as green manure (Antal 2005).

Many researchers have defined the most important criteria and characters of green manure plants in their works. The main properties of crops utilized as green manure can be characterized with the following features according to Füleky (1999), Nagy (2002) and Szabó (2003):

- short vegetation period, herbaceous plants with large leaf area and high soil coverage,

- low demand on water,

- good nutrient mobilizing and uptake ability,

- deep and dense root system,

- tolerance and resistance against pathogens and pests,

- favourable effect as pre-crop,
- simple and cost-effective sowing material, production, - well-adapted to extreme climatic conditions.

In order to achieve positive results with green manure crops, thorough and considered planning is essential. Many researchers carried out studies in which the positive effect of green manure crops is manifested. Cherr et al. (2006) emphasize that the production of green manure crops is a complex project, the success of which is depending on the relationships between the green manure plant, environment and technology.

According to the statements of Kahnt (1985) and Birkás et al. (2001) green manure crops accumulate nitrogen and humus in the soil, reduce leaching of minerals from the soil, and they mainly accumulates $\mathrm{N}$ mobilized by the main crop, decrease the leaching of mineral substances, deflation and erosion, result crumbly soil conditions and help the protection against pests (nematodes) and diseases, distract light from other weeds and have antagonistic effect. Talgre et al. (2012) concluded in their study that the products of legume plants increase soil nitrogen and carbon stock and thus they improve the physical state of soils. According to Birkás (2006) green manure crops decrease soil compaction and thus soil preparation measurements for the follow-on crop can be executed with lower energy input and less harmful effects. Furthermore, frozen plant residues protect soil surface from siltation and the following cracking after drying in the wintertime. Birkás $(2004,2017)$ estimates as positive effects in her works that green manure stimulates soil edaphon, has positive effects on earthworm populations (biological indicators), and may compensate the organic substance decreasing effect of intensive soil tillage. Furthermore, the production of green manure crops results in increasing soil water capacity (Antal 2005). It also has to be added that the utilization of mineral fertilizers is better on soils where green manure was grown before (Szabó 2003). Based on his experiments Mikó (2009) concluded that the application of low amount - $50 \mathrm{~kg} \mathrm{ha}^{-1}$ - of nitrogen had favourable effect on the amount of available phosphorous and potassium content as well.

There is intensive plant production when targeted soil tillage, crop rotation and nutrient supply is combined with integrated crop protection and the selection of plant species adapted to the production site. Therefore green manure application has to be planned because its effect is versatile and unwanted secondary effects may occur as well (Kahnt 1986). Basic criterion of green manure production according to Kahnt (1986) is to know the target, effects and secondary effects of their application. Sowing material, just as time and soil conditions of sowing have to be chosen with caution. Birkás (2006) mentioned first the amount of fallen precipitation during the middle of the summer as the most important limiting factor. In her work she emphasizes that green manure crops can be produced in a safe way only using sowing and production methods that hinder soil water stock loss. Nagy (2002) and Kahnt (1986) made more exact definitions: for the successful production the lower limit of yearly 
precipitation amount is 600-700 mm. Kahnt (1986) draws the attention of producers to the fact that in case the wrong green manure crop has been chosen on a drought production site or too high level of nitrogen has been applied, the production will not be successful due to the high water uptake. Furthermore, green manure seeds with hard husks may mean further risk, because they may tilt and overwinter and then they may cause damages in the main crop population as weeds. Furthermore in case too high amount of biomass is ploughed or tilled into the soil, the follow-on crop may be affected as well. This fact is confirmed by Birkás (2006): in case the green manure is tilled and mixed into the soil in larger bunches, local N-deficiency may occur. The producer has to face financial losses also when the green manure crop develops too low amount of biomass, without reaching the set target. Sowing time of green manure crops has to be chosen properly and carefully because in case it emerges wrong, the coverage of the population will be insufficient and if the root system is inadequate, soil structure will not be improved either (Birkás 2006). According to Szabó (2003) the effect of green manure crop production is rather short-term, 1-2 years. It is a consequence of that humus produced from it is no stable, but nutrient humus. Furthermore, green manure increases the nutrient content of the upper soil level only, because the mineralized nutrients originate from the deeper soil layers of the same site. Legumes are an exception to this statement. Safety of green manure crop production changes: depending on the given crop year the amount of the produced biomass is different, thus its yield increasing effect is changing or may even be absent as well (Antal 2005). Some scientists suggest that winter cereal shall not be sown after any green manure crop, because green manure crops cannot produce a biomass during the shorter vegetation period of 40-45 days that would be worth ploughing and tilling into the soil. Furthermore, hollow soil structure is not favourable for cereals either (Józsa 1985).

\section{MATERIALS AND METHODS}

This article is a special mixture of the experimental work and literature based statements. Small plot field experiment has been set up at the Látókép Experimental Station of Plant Production of the Farm and Regional Research Institute of the University of Debrecen during the summer 2017. The Station is located on the loess ridge of the region Hajdúság approximately $15 \mathrm{~km}$ far from the city of Debrecen, along the main road Nr. 33 . The experimental soil can be soil genetically classified as a calcareous chernozem soil.

Soil analysis was performed before the experiment was set up, according to the results of which it can be stated that physically the soil is loamy and its $\mathrm{pH}$ is almost neutral. Its phosphorous supply can be regarded as medium, while its potassium supply is rather medium-good. Soil humus content is about 2.6-2.8\%; the depth of the humus soil layer is around $80 \mathrm{~cm}$.
Regarding the characteristic water management result data and the data published by Várallyay the soil can be classified into the $4^{\text {th }}$ water management group, which means a medium water holding capacity.

Fodder pea was sown on $21^{\text {st }}$ July 2017 , while the rapeseed hybrid Arkazo as green manure crop on the $8^{\text {th }}$ August. Green manure plants were tilled into the soil on the $4^{\text {th }}$ October. After that the main crop, the winter wheat variety MV Csillag was sown. The other studied main crop of our study, maize will be sown during the spring of 2018 as well.

In the present experimental crop year plant development dynamics of both studied species, just as the time of the main phenological stages, agronomical parameters of populations and plant health conditions will be also monitored. In the vegetation period photosynthetic capacity, just as its dynamic change, leaf area duration and after the harvest yield of the two main crops, just as their most important quality parameters will be evaluated as well. The present study will cover the monitoring of changes in soil conditions too. These soil analyses include mainly the determination of soil organic matter stock and the quantity and quality of humus, just as further soil parameters.

\section{RESULTS AND DISCUSSION}

In a research between 2007 and 2009, Gyuricza (2014) stated according to their results that unfertilized phacelia produced only a biomass of $4.8 \mathrm{t} \mathrm{ha}^{-1}$ in 2009 , but in the wet crop year of 2007 its production was $18.4 \mathrm{t} \mathrm{ha}^{-1}$. In case of the green manure crop phacelia the green biomass higher than $10 \mathrm{t} \mathrm{ha}^{-1}$ could only be produced with additional nitrogen supply.

However, green biomass was increased by 1.913.95-times, due to the spring application of nitrogen regarding the average of the three studied crop years the increment was 3.11-times higher. The drought in the crop year 2009 was unfavourable for phacelia, but its stress-tolerance was significantly increased by $\mathrm{N}$ application and its water-utilization was also improved, thus $16.7 \mathrm{t} \mathrm{ha}^{-1}$ of biomass was produced.

In case of mustard the amount of produced biomass was lower than $10 \mathrm{t} \mathrm{ha}^{-1}$ only in the crop year 2008 without any additional $\mathrm{N}$-supply $-7.3 \mathrm{t} \mathrm{ha}^{-1}$. In contrast the application of $50 \mathrm{~kg} \mathrm{ha}^{-1} \mathrm{~N}$ active substance increased the amount of produced biomass of this plant to $31.7 \mathrm{t} \mathrm{ha}^{-1}$. Regarding the average of the three studied crop years the increment of biomass amount was 3.09-times higher, thus green biomass of $35.4 \mathrm{t}$ $\mathrm{ha}^{-1}$ was produced on the average.

In case of fodder radish balanced yield levels were observed: different crop years affected the yield of this plant in a lower extent. The amount of produced biomass ranged between 9.8 and $13.9 \mathrm{t} \mathrm{ha}^{-1}$ without any additional fertilizer application, and between 27.6 and $34.4 \mathrm{t} \mathrm{ha}^{-1}$ when fertilized. The application of lowamount $\mathrm{N}$-fertilizer active substance increased biomass yield amount 2.19-3.33-times higher. Regarding the absolute dry matter amount similar tendencies were observed as described in case of green biomass, but 
due to the application of $\mathrm{N}$-fertilization the increment of dry matter was $94 \%$ lower in case of phacelia than the extent of green biomass increment, while in case of the mustard $43 \%$ and for fodder radish $118 \%$ lower extents were measured. This can be explained by the fact that $\mathrm{N}$-application increased water content of the crops as well. The studies confirmed that the application of low-amount fertilizer multiplied green manure crops' biomass.

As response to the application of low amount 50 $\mathrm{kg} \mathrm{ha}^{-1}$ results in the production of balanced green biomass amounts, just as significant NPK-content in case of all three studied crops. However, without any additional nitrogen supply inadequate amount of biomass was produced in case of the studied production site with such weak properties. Regarding the average of the treatment combinations the highest biomass yield was measured in case of fodder radish: $61.9 \mathrm{t} \mathrm{ha}^{-1}$. Phacelia, mustard and spring rapeseed produced similar high and about similar green biomass yield amounts (41.7 $\mathrm{t} \mathrm{ha}^{-1}, 39.4 \mathrm{t} \mathrm{ha}^{-1}, 40.4 \mathrm{t} \mathrm{ha}^{-1}$ ). The mixture of phacelia-mustard-fodder radish produced lower biomass yield $\left(48.5 \mathrm{t} \mathrm{ha}^{-1}\right)$ than fodder radish only; the yield of this mixture was similar to the average of the component plants. The mixture of vetch and oat produced a biomass of $32.7 \mathrm{t} \mathrm{ha}^{-1}$ regarding the average of the treatment combinations. In case of legumes average biomass yields of 20-25 $\mathrm{t} \mathrm{ha}^{-1}$ were measured. Buckwheat produced the lowest average biomass yield: $19.8 \mathrm{t} \mathrm{ha}^{-1}$. According to the results of the research work it can be stated that the application of low-amount $\left(50 \mathrm{~kg} \mathrm{ha}^{-1}\right)$ nitrogen resulted in the increment of green biomass yield. Furthermore as a result of nitrogen fertilization the amount of plantextracted nitrogen increased 3.9-4.1-times. The applied nitrogen active substance improved the uptake of phosphorous and potassium as well. The amount of plant-extractable phosphorous was increased to 3.1times higher in case of phacelia, while in case of mustard to 2.5-times, and for fodder radish to 1.9times higher. The potassium content per hectare was increased to 2.4-times in case of phacelia, while for mustard to 3.5-times and fodder radish to 2.2-times higher.

The amount of nutrients mobilized by green manure crops was significant. Regarding the average of the treatments the oat-vetch mixture $\left(299.8 \mathrm{~kg} \mathrm{ha}^{-1}\right)$ and lupin $\left(255.1 \mathrm{~kg} \mathrm{ha}^{-1}\right)$ contained the highest nitrogen amounts. Mustard and fodder radish mobilized also more than $200 \mathrm{~kg} \mathrm{ha}^{-1}$ nitrogen regarding the average of the treatments. The mixture of phacelia-mustardfodder radish, spring rapeseed and sweet clover left over almost the same amount of nitrogen: $172-183 \mathrm{~kg} \mathrm{ha}^{-1}$ $\mathrm{N}$ after tilling them into the soil. Buckwheat of low nitrogen content, just as crimson clover produced under unfavourable conditions, thus resulting low biomass amount, thus containing low nitrogen amount per hectare both contained $100 \mathrm{~kg} \mathrm{ha}^{-1}$ nitrogen on the average.

Regarding the average of the treatments the highest phosphorous amount $104.7 \mathrm{~kg} \mathrm{ha}^{-1}$ was mobilized by fodder radish. Phacelia, mustard, the mixture of phacelia-mustard-fodder radish and oat-vetch mixture contained equally contained a phosphorous amount equal to $80 \mathrm{~kg} \mathrm{ha}^{-1} \mathrm{P}_{2} \mathrm{O}_{5}$. After it's tilling into the soil spring rapeseed increased phosphorous supply of the after-crop by $58.8 \mathrm{~kg} \mathrm{P}_{2} \mathrm{O}_{5} \mathrm{ha}^{-1}$ on the average. The phosphorous amounts mobilized by buckwheat, lupin and sweet clover were similar: $50.9 ; 48.2 ; 46.4 \mathrm{~kg} \mathrm{ha}^{-1}$ respectively. Similar to the fact described in case of the nutrient nitrogen the green manure crop crimson clover showed the lowest $\mathrm{P}_{2} \mathrm{O}_{5}$-content per hectare, that can be explained by the lowest dry matter content per hectare of this plant.

Further results of the research work confirmed that mustard, fodder radish and the mixture of phaceliamustard-fodder radish, just as mustard-fodder radish mixture had excellent weed control effect, their populations were completely free from weeds in all studied treatment combinations. The weak early development of phacelia could be compensated by the dense population in the later vegetation stages effectively. The excellent competitiveness of mustard and fodder radish could also be revealed: in some cases they even hindered the development of phacelia. The highest rate of weed coverage was observed in case of the crimson clover populations among the studied green manure crops. Average weed coverage of it was $21.7 \%$, but in some treatment combinations it exceeded 30\% even (Mikó 2004).

The small-plot experimental results of Csavajda (2003) confirm that the biomass yield of green manure crops may vary depending on the given crop year. In both studied crop years the highest biomass yield was produced by the mixture of phacelia-fodder radish $(1998-34.6$ t, $1999-41.03$ t). The lowest produced yield was measured in case of fodder radish (1998 15.95 t, 1999 - 33.43 t).

In their research work executed between 2004 and 2009 Talgre et al. (2012) determined following results: the lowest dry matter yield was measured in case of the crop birdsfoot trefoil (only $4.94 \mathrm{t} \mathrm{ha}^{-1}$ ) while the highest for hybrid alfalfa $8.02 \mathrm{t} \mathrm{ha}^{-1}$. Nitrogen content of the total biomass produced per hectare was 113$206 \mathrm{~kg}$, while phosphorous content ranged between 17 and $24 \mathrm{~kg}$ and potassium between 89 and $144 \mathrm{~kg}$. Furthermore, in all three studied crop years crimson clover, just as alfalfa and hybrid alfalfa proved to affect the yield amount of winter wheat yield amount.

\section{CONCLUSION}

Parallel to the growth of humankind population, more and more food will be needed. However, soil physical structure and agricultural state can decline fast due to the intensive soil utilization. An alternative solution is essential that exclude or minimize the acidifying effect of mineral fertilizers and that is a far more cost-effective method for both producers and the future. Due to the decreasing number of livestock in Hungary insufficient amount of manure can be produced.

After the thorough evaluation of possibilities and risks the production of green manure crop species is 
especially recommended on soils with low organic substance content, where the depth of soil melioration is limited, or on sites affected by wind or water erosion (Birkás 2006). The production of green manure crops is especially recommended where crop rotation systems have been simplified and cereals are dominant, or in case of heavy soils, just as wetlands (Kahnt 1986). Experiments proved that, the green biomass amount can be even the doubled with the application of low nitrogen amounts, and the fertilization treatment improved the nitrogen uptake and the nutrition mobilization of the green manure crops. Furthermore there is significant correlation between the effect of green manure and the yield of the main crop.

Due to the lack of fossil resources, the expensive measurements and the decreasing amount of manure growing significance of green manure crops will increase in the future and they will spread to further production sites and soils. The production of green manure crops can be successful and profitable, if adequate nutrient supply, weed control and soil cultivation are applied parallel. This means in case the demands of green manure crops are covered as well (Cherr et al. 2006).

Objective of the set experiment is to find new technological solutions that are suitable for the sustainable crop production with inadequate crop rotation, organic substance recovery conditions or under more unfavourable climatic conditions.

\section{ACKNOWLEDGEMENTS}

The work/publication is supported by the EFOP3.6.3-VEKOP-16-2017-00008 project. The project is co-financed by the European Union and the European Social Fund.
Antal J. (1993): A zöldtrágyázás szerepe a talajtermékenység fenntartásában. Agrofórum. 2: 4-10.

Antal J. (2005): Növénytermesztéstan 2. Mezőgazda Kiadó Budapest. 105.

Birkás M.-Gyuricza Cs.-Percze A.-Schmidt R.-Vincze M. (2001): A szántóföldi talajhasználat alapjai. Akaprint Nyomdaipari Kft. Budapest. 135-165.

Birkás M. (2006): Környezetkímélő alkalmazkodó talajművelés. Akaprint Nyomdaipari Kft. 136-149.

Birkás M. (2017): Földművelés és földhasználat. Mezőgazda lap- és könyvkiadó. Budapest. 206-210.

Birkás, M.-Jolánkai, M.-Gyuricza, Cs.-Percze, A. (2004): Tillage effects on compaction, earthworms and other soil quality indicators in Hungary. Soil \& Tillage Research. 78: 185-196.

Cherr, C. M.-Scholberg, J. M. S.-McSorley, R. (2006): Green manure approaches to crop production: a synthesis. Agronomy Journal. 98: 302-319.

Csavajda É. (2003): A talajtermékenységet befolyásoló növények és növénytársítások termőképességének vizsgálata. Veszprémi Egyetem. Növénytermesztési és Kertészeti Tudományok Doktori Iskola. 68-85.

FAOSTAT (2017): Land Use. http://www.fao.org/faostat/en/ \#data/RL

Füleky Gy. (1999): Tápanyag-gazdálkodás. Mezőgazda Kiadó. Budapest. 262-267.

Gyuricza Cs. (2014): A talaj és környezetminőség javításaés fenntartása növénytermesztési módszerekkel. Szent István Egyetem. Növénytudományok Doktori Iskola. 60-64.

Józsa L. (1985): A másodvetésủ szántóföldi növények termesztése. Mezőgazdasági Kiadó. Budapest. 203.

Kahnt G. (1986): Zöldtrágyázás. Mezőgazdasági Kiadó. Budapest. $39-53$.
KSH (2016): 4.3.1. Fontosabb gabonafélék termésátlaga, 19212015. https://www.ksh.hu/docs/hun/agrar/html/tabl1_4_3_1. html

KSH (2017): 4.1.1. Fontosabb gabonafélék vetésterülete, 19212016. https://www.ksh.hu/docs/hun/agrar/html/tabl1_4_1_1. $\mathrm{html}$

KSH (2017): 5.1.1. Szarvasmarha-, sertés-, ló- és juhállomány, 1851-2016. https://www.ksh.hu/docs/hun/agrar/html/tabl1_5_ 1_1.html

KSH (2018): 4.1.7. Értékesített műtrágya mennyisége hatóanyagban (2000-)*. https://www.ksh.hu/docs/hun/xstadat/xstadat_eves/ i_omf002.html

Mikó P. (2009): A zöldtrágyázás talaj állapotra és utónövényre gyakorolt hatásainak vizsgálata. Doktori értekezés. Szent István Egyetem. Növénytudományi Doktori Iskola. 69-86.

Mikó, P.-Kovács, G. P.-Percze, A.-Gyuricza, Cs. (2015): Effect of different $\mathrm{N}$ nutrient contents on biomass of green manure as second crop, under unfavorable climate conditions in Hungary. Applied Ecology and Environmental Research. 14. 3: 309-324.

Nagy Z. (2002): Zöldtrágyázással a fenntartható környezetért. Gyakorlati Agrofórum. 13. 2: 23-26.

Statisztikai jelentések. (2013): Tájékoztató jelentés a nyári mezőgazdasági munkáról 18. Agrárgazdasági Kutató Intézet. Budapest. 39.

Statisztikai jelentések (2017): Tájékoztató jelentés a nyári mezőgazdasági munkáról 22. Agrárgazdasági Kutató Intézet. Budapest. 39.

Szabó I. (2003): Talajművelés és trágyázás. Szaktudás Kiadó Ház. Budapest. 46-48.

Talgre, L.-Lauringson, E.-Roostalu, H,-Astover, A.-Makke, A. (2012): Green manure as a nutrient source for succeeding crops. Plant Soil Environ. 58. 6: 275-281. 